\title{
New Distributional Record of Greater Amberjack Seriola dumerili (Risso, 1810) (Perciformes: Carrangidae) from the Eastern Arabian Sea, India
}

\author{
K.M. Rajesh, Sujitha Thomas, Sandhya Sukumaran¹, G.B. Purushottama,
} G.D. Nataraja, A.P. Dineshbabu, Prathibha Rohit, P.U. Zacharia ${ }^{1}$

10.18805/IJAR.B-4715

\begin{abstract}
Background: The fishes of the family Carangidae forms one of the largest families of bony fishes, representing about 140 species, widely distributed in all tropical and temperate marine waters of the world. In recent past, fishes of this family are exhibiting new geographical distribution which could be attributed to climatic variability.

Methods: The specimens were collected from multiday trawl boats operated along Karnataka coast. Morphometric and meristic characteristics together with genetic analysis using DNA bar coding was used to validate the identity of the specimen. Spatial distribution map of the species in Indian Ocean was generated using the information from the present study and available literature.

Result: The morphometric and meristic characteristics of the specimens of greater amberjack, Seriola dumerili collected during the study were comparable with the previous investigations. The phylogenetic tree constructed using sequences of COI (MW974826 and MW974827) of the Seriola species showed distinct clustering among species with significant bootstrap values confirming the identity to the extent of $99 \%$ with the sequences of Seriola dumerili deposited in NCBI GenBank. This study confirms the first distributional record of Seriola dumerili from the eastern Arabian Sea.
\end{abstract}

Key words: Arabian sea, Carrangidae, Greater amberjack, Seriola dumerili.

\section{INTRODUCTION}

The family Carangidae forms one of the largest families of bony fishes comprising various marine fishes that are ecologically and commercially important species such as the jacks, scads, trevallies, pampano, amberjacks and queenfishes (Rekha et al. 2010; Abdussamad et al. 2013). The fishes of this family represent about 140 species, widely distributed in all tropical and temperate marine waters of the world (Nelson, 1994; Kim et al. 1997). Carangid fishes are widely distributed along both west and east coast of India mainly concentrated in coral and rocky beds representing 60 species having intricate morphological and meristic characters, which makes their identification highly complicated (Abdussamad et al. 2008, 2013). Presence of two separate dorsal fins, lateral line scutes and two detached anal spines, cutaneous fleshy lateral keels, dorsal and ventral grooves on caudal peduncle with wide variation in shape of the body, size, scale pattern and colouration are the general characteristics of the fishes of this family (SmithVanitz, 1984). However, the detached anal spines are visible externally only during younger stages in jacks and become resorbed or embedded beneath the skin in adults with no lateral line scutes.

The greater amberjack, Seriola dumerili is widespread in subtropical and temperate waters of the world Ocean (Mohamed et al. 2018; Manooch and potts, 1997) and often associated with rocky reefs between the depth range of less than 20 and 80 metres but also recorded at depths of up to $360 \mathrm{~m}$ (Fischer et al. 1987). Juveniles of this species always
ICAR-Central Marine Fisheries Research Institute, Mangalore Regional Centre, Mangaluru-575 001, Karnataka, India.

${ }^{1}$ ICAR-Central Marine Fisheries Research Institute, Kochi-682 018, Kerala, India.

Corresponding Author: K.M. Rajesh, ICAR-Central Marine Fisheries Research Institute, Mangalore Regional Centre, Mangaluru575 001, Karnataka, India. Email: rajeshmkm3@rediffmail.com

How to cite this article: Rajesh, K.M., Thomas, S., Sukumaran, S., Purushottama, G.B., Nataraja, G.D., Dineshbabu, A.P., Rohit, P., Zacharia, P.U. (2021). New Distributional Record of Greater Amberjack Seriola dumerili (Risso, 1810) (Perciformes: Carrangidae) from the Eastern Arabian Sea, India. Indian Journal of Animal Research. DOI: 10.18805/IJAR.B-4715.

Submitted: 12-07-2021 Accepted: 25-10-2021 Online: 27-11-2021

moves in school but adults are mostly solitary (Khalaf, 2004). The greater amberjack, one of the largest carangid, which supports important recreational and commercial fisheries, grows to a maximum of 1.9 m length and weighs $80.6 \mathrm{~kg}$ (Kulbicki et al. 1993; Thompson et al. 1999). It is an opportunistic predator, feeds voraciously on teleosts, crustaceans, molluscs and sea grass (Andaloro and Pipitone, 1997; Badalamenti et al. 1993; Mohamed et al., 2018) while juveniles feed on plankton, small invertebrates and sea grass (Feitoza et al. 2005).

The previous studies recorded the species only from South Africa northward to Algoa Bay and the Gulf of Western Indian Ocean and from Bay of Bengal in the eastern Indian 
Ocean. In addition, it was reported from Japan, Australia and the Hawaiian Islands of Indo-west Pacific the Bay of Bengal, east coast of India (Fischer and Bianchi, 1984; Abdussamad et al. 2008). Hence, the specimens described in this study confirm the first distributional record of $S$. dumerili from the eastern Arabian Sea based on the morphomeristic characteristics and molecular analysis.

\section{MATERIALS AND METHODS}

In the present study, a total of 28 specimens of $S$. dumerili were procured from Mangalore $\left(12^{\circ} 853^{\prime} \mathrm{N}, 74^{\circ} 833^{\prime} \mathrm{E}\right)$ and Malpe Fishing Harbours $\left(13^{\circ} 347^{\prime} \mathrm{N}, 74^{\circ} 701^{\prime} \mathrm{E}\right)$ of Karnataka during December 2020 to April 2021. The specimens collected were caught from multiday trawl boats operating hook and lines at a depth of $60-80 \mathrm{~m}$. Fresh specimens were brought to the laboratory of the Regional Centre of ICARCentral Marine Fisheries Research Institute, Mangalore in iced condition for the detailed morphological and molecular investigations. Specimens were photographed in fresh condition and identified based on the key given by SmithVaniz, (1984). The morphometric and meristic measurements were taken following standard procedure (Hubs and Lagler, 2004) and compared with the published information available about this species from different parts of the world (Abdussamad et al. 2008; Sley et al. 2016; Luzhmiak et al. 2020). The morphometric measurements were taken for each specimen with an accuracy of $0.01 \mathrm{~mm}$ and total body weight was recorded to the nearest $0.1 \mathrm{~g}$ using digital calliper and electronic weighing balance respectively. The natural colour patterns and tones were recorded from freshly collected specimen as these characters may be lost completely or partially when stored using preservatives.

\section{Genetic analysis}

Before tissue collection for DNA analysis, the scissors and forceps were cleaned thoroughly of any possible DNA between each sample by plunging it into high concentration ethanol and igniting with a lighter. Muscle tissue (about 5 $\mathrm{mm}^{2}$ ) was taken from caudal peduncle area with a cleaned scissors and preserved in 95\% ethanol (10:1 ratio) in small plastic vials at room temperature for further analysis.
Triplicate samples were taken labelled with sample numbers, date of collection and species and other information like locality, type of collection fish length and sex, etc., was recorded on data sheet (FAO, 2016).

\section{DNA extraction and amplification of the Cytochrome C Oxidase 1 (COI) gene sequences}

DNA of the specimens was extracted using standard phenol/ choloroform extraction protocol and a universal primer (Folmer et al. 1994) was used for the amplification of mitochondrial Cytochrome $\mathrm{C}$ oxidase 1 (COI) gene using PCR. The PCR products were sequenced subsequently using the primer (LCO1490 and HC02198; Folmer et al. 1994) and a 650bp region of COI genes submitted to NCBI GenBank with accession nos. MW974826 and MW974827.

\section{Materials examined}

Seriola dumerili (Risso, 1810): 28 ex: 425-495mm TL, 745$1107 \mathrm{~g} \mathrm{TW}$, collected from Mangalore and Malpe Fishing harbours, Karnataka, India, 29 December 2020, 27 January 2021, 11, 16 February 2021, 17 March 2021 and 20 April 2021.

\section{RESULTS AND DISCUSSION \\ Seriola dumerili (Risso, 1810), Greater amberjack}

\section{Morphometric measurements}

Slightly compressed and elongated body (Fig 1) with depth at first and second dorsal fin origin was about 24.2-28.9 and $23.8-27.7 \%$ of the TL respectively (Table 1 ). The first gill arch had 5-6 and 14-16 gillrakers on upper and lower lobe respectively. Two dorsal fins separated by a narrow space $0.65-1.18 \% \mathrm{TL}$; first dorsal fin with seven spines and second dorsal had one spine and 31-32 rays. First two spines of anal fin feebly developed followed by a spine and 18-20 soft rays. Pelvic fins (11.31-14.82\% of TL) slightly longer than pectoral fins $(10.37-12.00 \%$ of $T L)$. Lateral line slightly curved with no scutes on it, a distinct caudal peduncle groove present. Very minute pointed teeth directed backward.

\section{Colouration}

Dorsal side of the body dark with olivacious or greenishblue, light silvery white on sides and belly; thick golden yellow
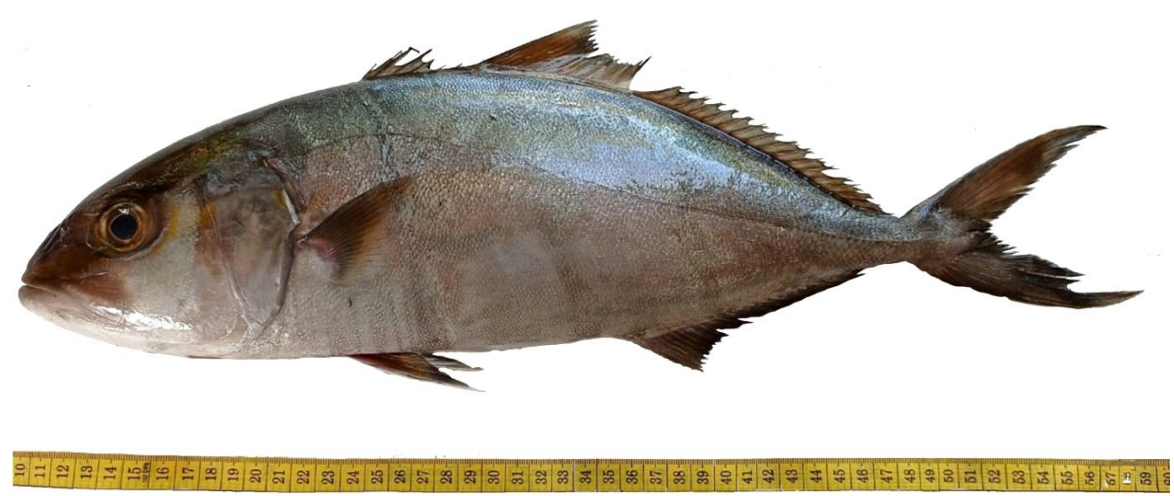

Fig 1: Seriola dumerili, $473 \mathrm{~mm}$, landed at Mangalore Fishery harbour, Karnataka, India. 
New Distributional Record of Greater Amberjack Seriola dumerili (Risso, 1810) (Perciformes: Carrangidae) from the Eastern...

Table 1: Morphometric and meristic characters of Seriola dumerili. Body proportions are expressed as a percentage of total length.

\begin{tabular}{|c|c|c|c|c|}
\hline \multirow[b]{2}{*}{ Species } & \multicolumn{4}{|c|}{ S. dumerili } \\
\hline & $\begin{array}{c}\text { Arabian sea, India } \\
\text { (Present study) } \\
n=28\end{array}$ & $\begin{array}{c}\text { Bay of Bengal, India } \\
\text { (Abdussamad et al. 2008) } \\
n=1\end{array}$ & $\begin{array}{c}\text { Mediterranean sea } \\
\text { (Sley et al. 2016) } \\
n=267\end{array}$ & $\begin{array}{c}\text { Black sea } \\
\text { (Luzhniak et al. 2020) } \\
n=1\end{array}$ \\
\hline Total weight $(\mathrm{g})$ & $745-1107$ & - & - & 934 \\
\hline Total length (TL mm) & $425-495$ & 489 & $155-1660$ & 447 \\
\hline In $\%$ of TL Fork length & $83.84-87.27$ & 86.0 & - & 90.60 \\
\hline Standard length & $74.74-81.82$ & 76.0 & - & 87.47 \\
\hline Head lengh & $22.83-26.56$ & 21.0 & $17.46-26.60$ & 22.37 \\
\hline Snout length & $7.58-8.67$ & 8.0 & - & - \\
\hline Eye diameter & $3.93-4.63$ & 4.0 & - & - \\
\hline Interorbital width & 8.69-9.89 & 7.0 & - & - \\
\hline Upper jaw length & $9.57-11.11$ & 9.0 & - & - \\
\hline lower jaw length & $9.05-10.59$ & - & - & - \\
\hline Caudal peduncle depth & $4.09-5.15$ & 4.0 & - & - \\
\hline Depth at I Dorsal & $24.24-28.87$ & 25.0 & $16.96-28.53$ & 20.36 \\
\hline Depth at II dorsal & $23.84-27.71$ & 27.0 & $16.42-26.08$ & 17.22 \\
\hline Maximum body depth & $25.27-28.87$ & 27.0 & - & - \\
\hline Pre-first dorsal length & $29.55-34.32$ & 28.0 & $25.71-48.39$ & 31.32 \\
\hline Pre-second dorsal length & $39.08-43.84$ & 38.0 & $34.24-48.72$ & 40.49 \\
\hline pre-pectoral length & $24.84-27.06$ & 21.0 & - & - \\
\hline Pre-pelvic length & $27.07-29.41$ & 24.0 & - & - \\
\hline Pre-anal length & $52.22-55.63$ & 50.0 & - & - \\
\hline Inter dorsal space & $0.65-1.18$ & 1.0 & - & - \\
\hline I Dorsal base length & $8.00-9.45$ & 10.0 & $6.56-13.52$ & 9.39 \\
\hline II dorsal base length & $31.83-36.36$ & 36.0 & $24.88-38.44$ & 36.24 \\
\hline Pectoral base length & $3.56-4.84$ & - & - & - \\
\hline Pelvic base length & $1.98-3.23$ & - & - & - \\
\hline Anal base length & $19.19-24.83$ & 24.0 & - & - \\
\hline I dorsal height & $4.04-6.35$ & - & - & - \\
\hline Il dorsal height & $8.42-10.37$ & - & - & - \\
\hline Anal height & $6.67-8.47$ & 12.0 & - & - \\
\hline Pectoral length & $10.37-12.00$ & 16.0 & $8.88-14.11$ & 11.86 \\
\hline Pelvic length & $11.31-14.82$ & 15.0 & - & - \\
\hline Pre-orbital length & $7.68-9.47$ & - & - & - \\
\hline Post-orbital length & $65.66-79.79$ & - & - & - \\
\hline \multicolumn{5}{|l|}{ Meristic counts } \\
\hline I dorsal spine & 7 & 8 & $6-7$ & 7 \\
\hline I dorsal rays & 0 & 0 & 0 & 0 \\
\hline II dorsal spine & 1 & 1 & 1 & 0 \\
\hline II dorsal rays & $31-32$ & 28 & $29-35$ & 34 \\
\hline Pectoral spines & 0 & 1 & 0 & 0 \\
\hline Pectoral rays & $19-21$ & 21 & $19-20$ & - \\
\hline Pelvic spines & 1 & 1 & 1 & - \\
\hline Pelvic rays & 5 & 4 & 5 & - \\
\hline Anal spines & 3 & $0+1$ & 3 & 2 \\
\hline Anal rays & $18-20$ & 19 & $18-21$ & 22 \\
\hline Gillrakers on the upper limb & $5-6$ & 8 & - & - \\
\hline Gillrakers on the lower limb & $14-16$ & 17 & $13-21$ & - \\
\hline Brancheostegal rays & 7 & 7 & - & - \\
\hline
\end{tabular}


strip on sides of head runs through the eyes along the centre of the body. First dorsal dark or greyish; second dorsal fin completely dark; Caudal and anal fins with slight yellow tinge.

Most of the morphometric and meristic characteristics (Table 1) of the specimens of greater amberjack, S. dumerili collected during the study were comparable with the previous investigations (Smith-Vanitz, 1984; Abdussamad et al. 2008; Sley et al. 2016; Luzhmak et al. 2020). The total length range of the specimens of $S$. dumerili obtained in the present study were narrower and comparable with the earlier reports from Black Sea (Luzhmak et al. 2020) and Bay of Bengal (Abdussamad et al. 2008), while the length range of the specimens of $S$. dumerili reported from the Mediterranean Sea (Sley et al. 2016) were broader. Similarly, the depth at first and second dorsal fins, maximum body depth, pre dorsal length of first and second dorsal fins were comparable with the ranges obtained by previous studies from Black Sea, Mediterranean Sea and Bay of Bengal (Table 1). However, the head length of the specimens of $S$. dumerili collected in this study are comparable with the specimens of Mediterranean Sea, but slightly higher than that of the specimens reported from Black Sea. Similar slight variations in the ranges of pectoral and pelvic fin lengths of $S$. dumerili were observed in the present study compared to the specimens of Mediterranean Sea and Black Sea (Table 1). The slight variations recorded in the proportions for some morphometric measurements such as head length, pre dorsal length, pelvic length, pectoral length, anal length and anal height in comparison to previous studies could be due to the differences in the size range of the specimens examined and geographic variations. Further, individual morphological traits are not depending on the species but on the temperature of the environment in which the fish grows (Nikolioudakis et al. 2014).

\section{Sequence alignment and analysis}

Molecular identification through DNA bar coding (Fig 2) was also employed for the confirmation of the species. The species identity of the samples of the present study was confirmed using NCBI, Blast. Molecular analysis confirmed $100 \%$ identity with the sequence of $S$. dumerili deposited in NCBI, GenBank. Further, the sequences of cytochrome c oxidase 1 ( $\mathrm{COI}$ ) of $S$. dumerili were aligned with sequences retrieved from GenBank of other valid species of $S$. dumerili, S. lalandi, S. quinqueradiata, S. hippos, S. fasciata, S. rivoliana and $S$. zonata using Clustal W in MEGA 6. A phylogenetic tree was constructed using UPGMA method with 1000 bootstraps. Tree topology was also tested using maximum likelihood, maximum parsimony and neighbour-joining methods. The tree was then rooted with CO1 sequences of Mugil cephalus retrieved from GenBank.

\section{Genetic analyses}

The phylogenetic tree constructed using sequences of COI (Fig 2) of the Seriola species showed distinct clustering among species with significant bootstrap values confirming the identity. The sequences of the present study also clustered with sequences of $S$. dumerili deposited in NCBI GenBank. Similar tree topology was also obtained when phylogenetic analyses were conducted using maximum likelihood, maximum parsimony and neighbour joining method.

This species is widely distributed in the Indo-West Pacific to Atlantic regions and were reported from South Africa, Persian Gulf, southern Japan and the Hawaiian Islands, eastern part of Indian Ocean (Bay of Bengal), Mariana and Caroline islands in Micronesia in the New Caledonia, Bermuda, Nova Scotia in the Western Atlantic,

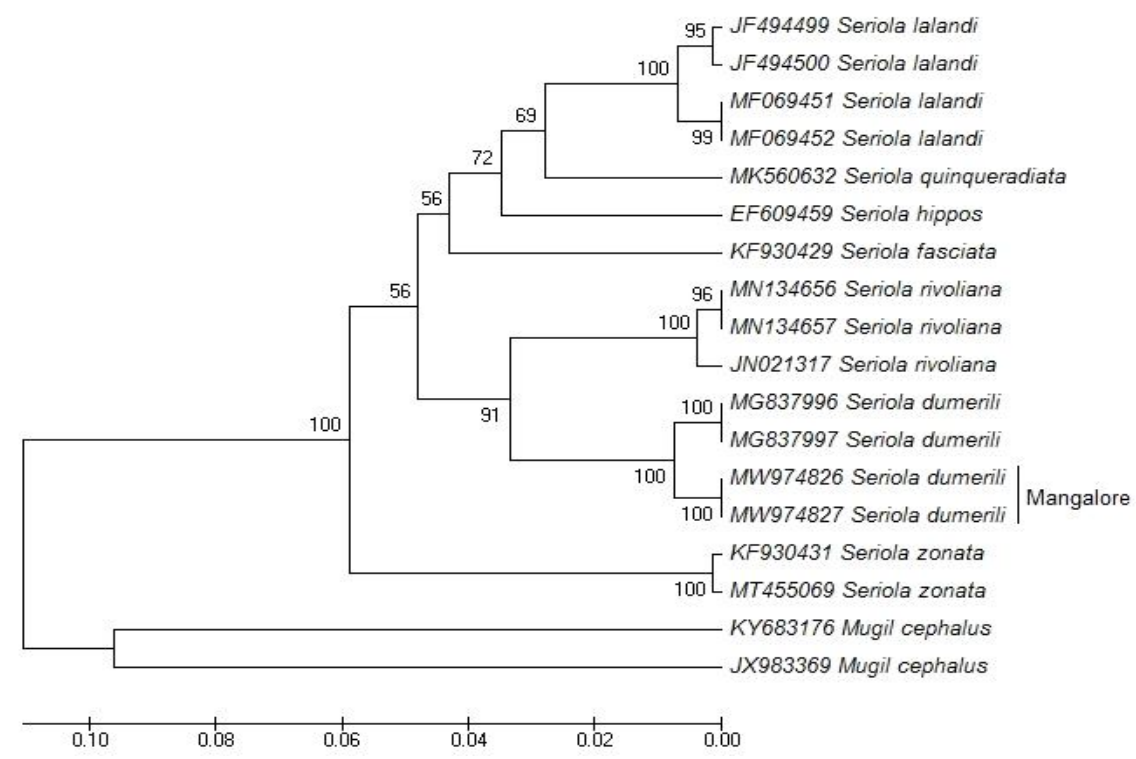

Fig 2: Phylogenitic tree of Seriola spp. based on DNA sequences of mitochondrial COI gene constructed using UPGMA method (MW974826 and MW974827, S. dumerili for the present study). 


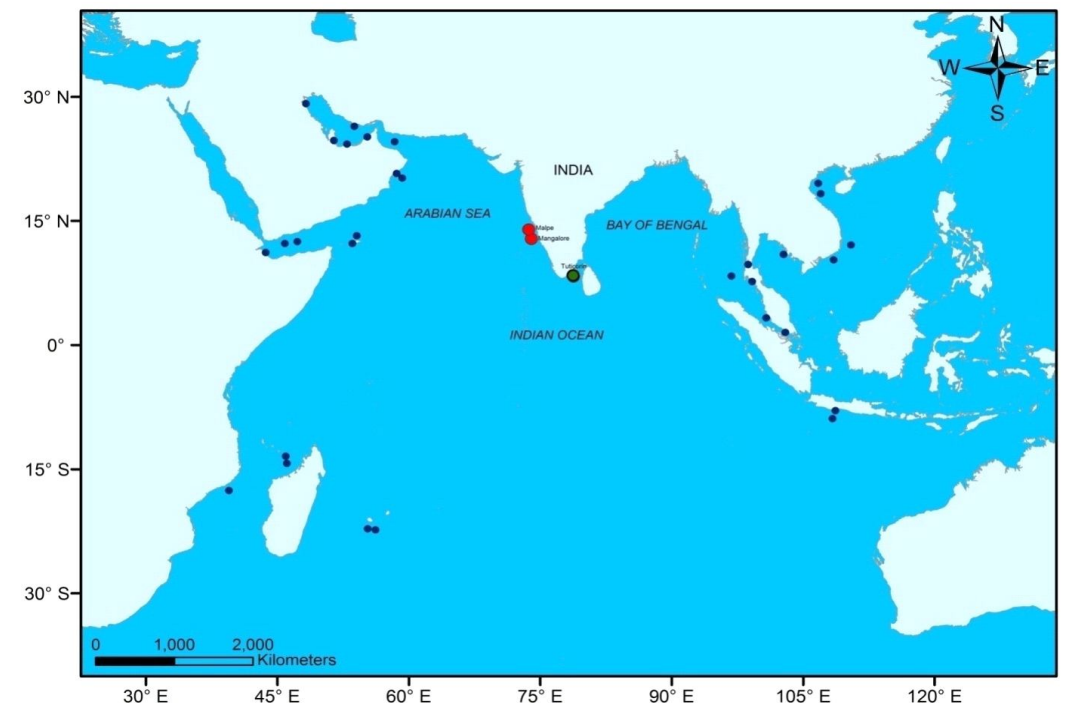

Fig 3: New distributional record of Seriola dumerili (Risso, 1810) in the southeastern Arabian Sea. The red circles indicates the present record, green circle indicates the report of Abdusamad et al. 2008 and blue circle indicates earlier records as given in

Fishbase (Froese and Pauly 2021) along the Indian Ocean.

Canada to Brazil, from the Gulf of Mexico and the Caribbean Sea, British coast (vagrant) to Morocco in the Eastern Atlantic and the Mediterranean (Smith, 1997; Abdussamad et al. 2008; Froese and Pauly 2021). However, the distribution of $S$. dumerili has not been reported in the eastern Arabian Sea till date and hence, this report confirms the first distributional record from eastern Arabian Sea (Fig 3). According to the information gathered from local fisherman, this species is caught at depth range of $60-80 \mathrm{~m}$ depth employing hooks and lines from the multiday trawl boats. The fishery of $S$. dumerili was reported previously along the Indian Ocean from South African Coast (SmithVanitz, 1984) and Tuticorin coast of India (Abdussamad et al. 2008). Hence, this indicates that $S$. dumerili could have extended its geographical range by migrating towards southeastern Arabian Sea from the African coast and/or from the Tuticorin waters, southeast coast of India. Molecular analysis also confirmed these findings as there was a $100 \%$ identity with sequence deposited in NCBI, GenBank. The substantial migration abilities of this species to move from Mediterranean waters to Black Sea have been reported (Lezhmiak et al. 2020). The size of the specimens collected in the present study $(425-495 \mathrm{~mm}$, TL) were comparable with that of the tuticorin waters (489 mm, TL), Bay of Bengal, India (Abdussamad et al. 2008) and Black Sea $(447 \mathrm{~mm}$, TL) (Luzhniak et al. 2020) but smaller than the reports from Mediterranean Sea (165-1650 mm TL) (Sley et al. 2016). Occurrence of small sized greater abmerjacks in shallow near shore waters and larger ones between 18 and $72 \mathrm{~m}$ and up to as deep as $360 \mathrm{~m}$ has been reported (Fischer and Bianchi, 1984). Thus, further studies are essential to investigate the abundance of greater amberjack in different depths and breeding and nursery grounds in the Arabian Sea.

\section{ACKNOWLEDGEMENT}

Authors are thankful to the Director, ICAR-CMFRI for the support and the facilities provided. The technical staffs, Naveen Raj and Sathyavathi and the research scholars Purbali Saha and Shailaja Salian of ICAR-CMFRI, Mangaluru are acknowledged for their assistance in the field and laboratory. The Authors are grateful to ICAR-NICRA for funding the work.

\section{REFERENCES}

Abdussamad, E.M., Joshi, K.K. and Jayabalan, K. (2008). Description of two lesser known jacks of the genus, Seriola (Family: Carangidae) from Indian waters and their comparison with a closely related species, Seriolina nigrofasciata (Ruppel, 1829). Journal of Marine Biological Association of India. 50(1): 57-61.

Abdussamad, E.M., Prathibha Rohit, Said Koya, K.P., Habeeb Mohammed, O.M.M.J. and Jeyabalan, K. (2013). Carangids (Family: Carangidae) in the seas around Indian subcontinent with description of macro-taxonomic characters for the field identification of genera and species. Indian Journal of Fisheries. 60(2): 21-36.

Andaloro, F. and Pipitone, C. (1997). Food and feeding habits of the amberjack, Seriola dumerili in the Central Mediterranean Sea during the spawning season. Cahiers de Biologie Marine. 38: 91-96.

Badalamenti, F., Danna, G., Lopiano, L., Scilipoti, D. and Mazzola, A. (1993). Feeding habits of young of the greater amberjack Seriola dumerili (Risso, 1810) along the N-W Sicilian Coast. Scientia Marina. 59(3-4): 317-323.

FAO, (2016). Marine species biological data collection manual- An illustrated manual for collecting biological data at Sea. 53 .

Feitoza, B.M., Rosa, R.S. and Rocha, L.A. (2005). Ecology and zoogeography of deep-reef fishes in Northeastern Brazil. Bulletin of Marine Science. 76(3): 725-742. 
Fischer, W. and Bianchi, G. (1984). FAO Species Identification Sheets for Fishery Purposes: Western Indian Ocean; (Fishing Area 51). Prepared and Printed with the Support of the Danish International Development Agency (DANIDA). Rome, Food and Agricultural Organization of the United Nations, vols. 1-6.

Fischer, W., Bauchot, M.L. and Schneider, M. (1987). FAO species identification sheets for fishery purposes: Mediterranean and Black Sea, Fishing Areas 37, Rome: Food Agric Org.

Folmer, O., Black, M., Hoeh, W.R., Lutz, R.A. and Vrijenhoek, R.C. (1994). DNA primers for amplification of mitochondrial cytochrome $\mathrm{c}$ oxidase subunit 1 from diverse metazoan invertibrates. Molecular Marine Biology and Biotechnology. 3: 294-299.

Froese, R. and Pauly, D. (2021) Fish Base 2021, version (02/2021) World Wide Web Electronic Publication Retrieved from http://www.fishbase.org.

Hubs, C.L. and Lagler, K.F. (2004). Fishes of the Great Lakes Region. Revised ed. Smith, G.R., rev University of Michigan Press, 199 pp. https://doi.org/10.3998/mpub.17658.

Khalaf, M.A. (2004). Fish fauna of the Jordanian coast, Gulf of Aqaba, Red Sea. Journal of King Abdulaziz University, Marine Science. 15(1): 23-50.

Kim, Y.S., Uk Kim, Y. snd Ahn, G. (1997). First record of the carangid fish, Seriola rivoliana from Korea. Korean Journal Ichthyology. 9(2): 244-247.

Kulbicki, M., Tham, M.G., Thollot, P. and Wantiez, L. (1993). Lengthweight relationships of fish from the lagoon of New Caledonia. NAGA, ICLARM Quarterly. 16(2-3): 26-29.

Luzhmiak, V.A., Chepurnata, T.A. and Zhivoglyadov, A.A. (2020). First discovery of greater amberjack Seriola dumerili (Carangidae) in Russian waters of the Black Sea coast of the Caucasus. Journal of Ichthyology. 60(2): 335-338.

Manooch III, C.S. and Potts, J.C. (1997). Age, growth and mortality of greater amberjack, Seriola dumerili from the U.S. Gulf of Mexico headboat fishery. Bulletin of Marine Science. 61(3): 671-683.
Mohamed, N.I., Amir, M.A.S., Ali, R.A.S. and Ali, S.M. (2018). Length-weight relationship, condition factor and food and feeding habits of Seriola dumerili (Risso, 1810, Carrangidae) in Al-Hamama, Estuary Libya Mediterranean Sea. International Journal of Fisheries and Aquaculture. 4(2): 1-18.

Nelson, J.S. (1994). Fishes of the World ( $3^{\text {rd }}$ Edn.). John Wiley and Sons, New York. 624.

Nikiloudakis, N., Koumoundouros, G. and Somarakis, S. (2014). Synchronization in allometric and morphological changes during metamorphosis: Comparison among four sparid species. Aquatic Biology. 21: 155-165.

Rekha, J.N., Joshi, K.K., Somy, K. and Geetha, P.M. (2010). Study on the Diversity of Carangid Resources off Cochin, Kerala. In Coastal Fishery Resources of India - Conservation and Sustainable Utilisation. Society of Fisheries Technologists. 98-108.

Sley, A., Hajjej, G., Laith, A.J., Jarbour, J. and Bouain, A. (2016). Morphometric and meristic characters of greater amberjack Seriola dumerili (Pisces: Carangidae) from the Gulf of Gabes, Tunisia. International Journal of Marine Science. 6(42): $1-8$.

Smith, C.L. (1997). National Abdubon Society Field Guide to Tropical Marine Fishes of the Caribbean, the Gulf of Mexico, Florida, the Bahamas and Bermuda. Alfred A, Knopf, Inc., New York. 720 .

Smith-Vanitz, W.F. (1984). Carangidae. In: FAO Species Identification Sheets for Fishery Purposes, [Fischer, W., Bianchi, G. (eds.)] Western Indian Ocean (fishery area 51) Volume I FAO, Rome.

Thompson, B.A., Beasley, M. and Wilson, C.A. (1999). Age distribution and growth of greater amberjack Seriola dumerili from the north central Gulf Mexico. Fishery Bulletin. 97: 362-371. 